\title{
The Effect of Ovarian Steroids on Colonic Epithelial Cell Proliferation and Apoptosis in Rats
}

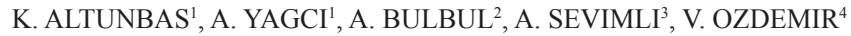 \\ ${ }^{1}$ Department of Histology and Embryology, Faculty of Veterinary Medicine, \\ ${ }^{2}$ Department of Physiology, Faculty of Veterinary Medicine, \\ ${ }^{3}$ Department of Pathology, Faculty of Veterinary Medicine, \\ ${ }^{4}$ Department of Anatomy, Faculty of Veterinary Medicine, \\ Afyon Kocatepe University, Afyon Turkey \\ Received November 15, 2006 \\ Accepted October 2, 2007
}

\begin{abstract}
Altunbas K., A. Yagci, A. Bulbul, A. Sevimli, V. Ozdemir: The Effect of Ovarian Steroids on Colonic Epithelial Cell Proliferation and Apoptosis in Rats. Acta Vet. Brno 2007, 76: 605-612.

The aim of this study was to investigate the effects of steroid hormones on proliferation and apoptosis in the colon crypt epithelium. The research was conducted on adult ovariectomized (Ovx) rats (Sprague Dawley). Ovx rats were injected for 15 days with $0.2 \mathrm{ml}$ of sesame oil (control; C), or $17 \beta$-oestradiol $(10 \mu \mathrm{g} / \mathrm{d}$; E), or progesterone $(2 \mathrm{mg} / \mathrm{d}$; P), or E + P. Proliferative activity in the colon was assessed by using proliferating cell nuclear antigen (PCNA) antibody. The proliferation index (PI), the number of PCNA positive cells divided by the total number of cells counted in the crypt column multiplied by 100 , was calculated. PI was lower in the hormonetreated groups, especially in group $\mathrm{P}$ compared to that in group $\mathrm{C}$. The apoptotic index (AI), the mean number of apoptotic cells, was detected by active caspase 3 immunoreactivity per crypt in the colon. AI was lower in the colon crypt epithelium of group E than that of the other groups. However, AI in the colon crypt epithelium in groups $\mathrm{P}$ and $\mathrm{E}+\mathrm{P}$ was higher than that of both group $\mathrm{E}$ and group $\mathrm{C}$. In addition, the colon crypt size (the number of epithelial cells lining one side of 10 well-oriented, longitudinally cut crypts) was considerably lower in group E than that of the other groups. In conclusion, we showed that the decrease of AI in group E was balanced by progesterone; the decrease of PI in group P was also depressed by oestrogen.
\end{abstract}

Rat, oestrogen, progesterone, ovariectomy, colon

The steady state of cell growth of healthy colonic epithelium is maintained by a dynamic balance between a continuing cell renewal and a shedding of cells at the surface of the colonic crypts (Johnson et al. 1994). This balance is regulated by various hormones including oestrogen and progesterone (Tutton and Barkla 1988) and growth factors (Jones et al. 1999).

Several studies have suggested that oestrogens may play a role in the colon in vivo and in vitro. However, conflicting data exist on the effects of oestrogens on the proliferative activity of colon epithelial cells. It has been shown that cell proliferation in the colonic epithelium is increased (Hoff and Chang 1979) or not changed in Ovx mice (Tutton and Barkla 1982) due to the effects of removed hormones. However, oestrogen treatment in Ovx animals inhibits DNA synthesis and decreases the proliferation (Hoff and Chang 1979; Hoff et al. 1981). Also 17ß-oestradiol treatment can reduce the frequency of dimethylhydrazineinduced large intestinal tumours significantly in rats (Smirnoff et al. 1999). Similarly, epidemiological reports have suggested that hormone replacement therapy, with or without progesterone, protects against colon cancer (Chlebowski et al. 2004; Farquhar et al. 2005; Nelson et al. 2002; Rossouw et al. 2002). Another epidemiological study showed that the withdrawal of oestrogen may increase the risk of microsatellite instability-positive colorectal cancer (Slattery et al. 2001). On the other hand, some in vitro studies have

Address for correspondence:

Dr. Korhan Altunbas

Afyon Kocatepe Universitesi

Veteriner Fakultesi Histoloji-Embriyoloji Anabilim Dali 03200

Afyonkarahisar,

TURKEY

Phone: 902722281312172

Fax: 902722281349

E-mail: korhana@aku.edu.tr

http://www.vfu.cz/acta-vet/actavet.htm 
demonstrated that oestrogens promote the proliferation of cultured colon cells (Xu and Thomas 1994; Domenico et al. 1996; Winter et al. 2000). In addition, it has been shown that ovariectomy retards large bowel tumour growth and oestradiol benzoate induces colon cancer cell proliferation (Tutton and Barkla 1982). Furthermore, a loss of the crypt length and a reduction of proliferative cells of the crypt in Ovx mice, and also a reversing effect of E replacement in these animals have been reported previously (Cho et al. 2007).

There is a common agreement that oestrogen can not act on the target tissues without binding to the oestrogen receptors (Hishikawa et al. 2003). Healthy colon tissues express both oestrogen receptor $\alpha(\mathrm{ER} \alpha)$ and $\operatorname{ER} \beta$ (Campbell-Thompson et al. 2001; Qiu et al. 2002; Xie et al. 2004; Cho et al. 2007). E and its receptors are the inhibitory modifiers that cooperate to regulate colon homeostasis (Cho et al. 2007). The two receptors function in opposite ways; ER $\beta$ activates apoptosis, whereas ER $\alpha$ acts as a survival factor. Thus, oestrogen induces apoptosis in colon cancer cells expressing ER $\beta$, whereas oestrogen does not have any effect in cells expressing both receptors (Qiu et al. 2002). Also, loss of ER $\beta$ in healthy colon tissues of mice results in a higher rate of cellular proliferation and a lesser amount of apoptosis (Wada-Hiraike et al. 2006). However, little is still known about the apoptotic or anti apoptotic effects of oestrogen in the colon cells.

Similar to oestrogen receptor, progesterone receptor has also been found in healthy and malignant colon tissues (Meggouh et al. 1991). Although recent epidemiological studies have reported that combined oestrogen and progesterone hormone replacement therapy reduces the incidence of colorectal cancer (Chlebowski et al. 2004; Farquhar et al. 2005; Nelson et al. 2002; Rossouw et al. 2002); however, the effects of progesterone and a combination of oestrogen and progesterone hormones on apoptosis and proliferation of colon epithelial cell are still unclear.

The aim of this study was to investigate the roles of oestrogen and progesterone hormones in the regulation of colonic tissue homeostasis.

\section{Materials and Methods}

Animals and treatment

Three-month-old Sprague-Dawley female rats obtained from the Department of Laboratory Animals, Gülhane Military Medical Academy Research Centre, Ankara, Turkey were used in the present study. All procedures were approved by the Ethics Committee at Afyon Kocatepe University, Turkey. Rats (totally n $=24$ ) at 12 weeks of age were anaesthetized by ketamine (Alfamine, Alfasan Int. BV3440 AB, Voerden Hollanda) $21.2 \mathrm{mg} / \mathrm{kg}$ i.p. and xylazine (Rompun ${ }^{\circledR}$ enj, Bayer Turk Kimya San. Ltd. Sti. Istanbul) $4.2 \mathrm{mg} / \mathrm{kg}$ i.p., and underwent bilateral Ovx. Small incisions were made bilaterally on the sides of the back to expose the ovaries retroperitoneally. The ovaries were clamped and removed and the uterine tubes were ligated. The muscle and skin were then sutured. All animals in all experimental groups were fed ad libitum with a commercial rat feed.

Two weeks after the operation, the rats were randomly divided into four groups:

1) group $\mathrm{C}(\mathrm{n}=6)$; Ovx rats were injected i.m. with $0.2 \mathrm{ml}$ of sesame oil

2) group $E(n=6)$; Ovx rats were injected i.m. with $17 \beta$-oestradiol (Sigma E8875;10 $\mu \mathrm{g} /$ day)

1) group $P(n=6)$; Ovx rats were injected i.m. with progesterone (Sigma P0130; $2 \mathrm{mg} /$ day)

2) group $E+P(n=6)$; Ovx rats were injected i.m. with a combination of both $17 \beta$-oestradiol $(10 \mu \mathrm{g} / \mathrm{day})$ and progesterone ( $2 \mathrm{mg}$ /day)

Rats were sacrificed by cervical dislocation after hormonal treatments carried out for 15 days. Distal colon samples were fixed immediately in $10 \%$ buffered formalin and embedded in paraffin using standard methods. Paraffin sections ( $5 \mu$ thick) were used for immunohistochemical stainings.

Immunohistochemistry for PCNA

Immunohistochemistry was used to assess proliferating cells by detection of proliferating cell nuclear antigen (PCNA). After deparaffinization and hydration, to unmask antigens, an antigen-retrieval procedure was performed by treating the samples three times in a microwave oven at $700 \mathrm{~W}$ for $5 \mathrm{~min}$ each time in $10 \mathrm{mM}$ citrate buffer ( $\mathrm{pH}$ 6). After cooling at room temperature, slides were treated with $3 \%$ hydrogen peroxide $\left(\mathrm{H}_{2} \mathrm{O}_{2}\right)$ in methanol for $10 \mathrm{~min}$ and then washed with PBS for $3 \times 5 \mathrm{~min}$. The sections were incubated in blocking reagent for $15 \mathrm{~min}$, and incubated overnight at $4{ }^{\circ} \mathrm{C}$ with anti-PCNA primary antibody at a $1: 1500$ dilution (Santa Cruz, sc-7907). Staining was completed with a Histostain Plus Kit (Zymed 85-9043) according to the manufacturer's instructions. The colour reaction product was developed with 3.3'-diaminobenzidine (DAB) (Zymed, 00-2020). All sections were counterstained with haematoxylin. 
Immunohistochemistry for active caspase 3

Immunohistochemistry for active caspase 3 was performed to determine the number of cells undergoing apoptosis in colon crypts. Sections were placed on poly-L-lysine coated slides and dried at room temperature. Sections were de-waxed, rehydrated through a graded ethanol series and washed with PBS. Sections were placed in antigen retrieval solution $(10 \mathrm{mM}$ citrate buffer, $\mathrm{pH}$ 6). Heat induced epitope retrieval was performed in the solution at $700 \mathrm{~W}$ for $10 \mathrm{~min}$ in a microwave oven and then endogen peroxidase activity was quenched by application of $3 \% \mathrm{H}_{2} \mathrm{O}_{2}$ in methanol for $10 \mathrm{~min}$. The sections were incubated in a blocking reagent for $15 \mathrm{~min}$ and incubated overnight at $4{ }^{\circ} \mathrm{C}$ with $1: 50$ dilution of active caspase 3 primary antibody (Abcam ab2302-50). Staining was completed with a Histostain Plus Kit (Zymed 85-9043) according to the manufacturer's instructions. The sections were incubated in DAB and counterstained with haematoxylin.

Quantification of crypt size, proliferation and apoptosis

The crypt size was defined as the number of epithelial cells lining one side of 10 well-oriented, longitudinally cut crypts (crypt column). The PCNA positive cells were identified as strongly stained cells. Cell proliferation was determined by counting the number of PCNA-positive cells per crypt column. The PI was defined as the ratio of PCNA- positive cells to the total counted crypt cells multiplied by 100 .

Immunopositive cells for active caspase 3 were counted in at least 50 crypts per animal and the average value was used for the AI.

Statistical analysis

Statistical analyses were performed by one-way analysis of variance (ANOVA) followed by post hoc Duncan multiple comparisons tests. Curve estimation in regression analysis was made by using SPSS software, Version 10.0 (SPSS Inc., Chicago, IL, USA). Values are presented as means \pm SE.

\section{Results}

The overall data regarding the crypt size, PCNA-positive cell number per crypt, PI and AI were summarized in Table 1 . The crypt size significantly decreased in group E compared to the other groups $(p<0.01)$. Although a slight decrease was observed in the crypt size of colon in groups $\mathrm{P}$ and $\mathrm{E}+\mathrm{P}$, there was no statistically significant difference in these groups.

Table 1. Effect of $17 \beta$-oestradiol (E) and progesterone $(\mathrm{P})$ on colonic epithelial cell proliferation and apoptosis in ovariectomized (Ovx) rats

\begin{tabular}{|c|c|c|c|c|c|}
\hline & $\mathrm{C}$ & E & $\mathrm{P}$ & $E+P$ & $P$ \\
\hline Crypt size & $52.89 \pm 1.96 \mathrm{a}$ & $34.81 \pm 2.12 b$ & $47.91 \pm 3.82 \mathrm{a}$ & $49.79 \pm 2.5 \mathrm{a}$ & $0.008 * *$ \\
\hline PCNA(+) cells /crypt & $28.19 \pm 2.38 \mathrm{a}$ & $14.68 \pm 1.72 \mathrm{bc}$ & $13.87 \pm 0.81 \mathrm{c}$ & $19.46 \pm 1.85 b$ & $0.000 * * *$ \\
\hline Proliferation index & $52.44 \pm 3.47 \mathrm{a}$ & $41.69 \pm 3.12 b$ & $28.87 \pm 0.51 \mathrm{c}$ & $38.85 \pm 3.1 \mathrm{~b}$ & $0.000 * * *$ \\
\hline Apoptotic index & $1.70 \pm 0.04 \mathrm{~b}$ & $0.55 \pm 0.15 \mathrm{c}$ & $2.79 \pm 0.54 \mathrm{a}$ & $2.59 \pm 0.10 \mathrm{a}$ & $0.000^{* * * *}$ \\
\hline \multicolumn{6}{|c|}{$\begin{array}{l}\text { Ovx rats were injected for } 15 \text { days with } 0.2 \mathrm{ml} \text { of sesame oil (control; C) or } 17 \beta \text {-oestradiol }(10 \mu \mathrm{g} / \mathrm{d} \text {; E) or } \\
\text { progesterone }(2 \mathrm{mg} / \mathrm{d} \text {; P) or } \mathrm{E}+\mathrm{P} \text {. } \\
\text { Crypt size is defined as the number of epithelial cells lining one side of } 10 \text { well-oriented, longitudinally cut crypts } \\
\text { PCNA }(+) \text { cell number/crypt is the number of proliferating cell nuclear antigen positive cells. Proliferation index } \\
\text { is number of PCNA positive cells divided by total number of cells counted in crypt column multiplied by } 100 \text { and } \\
\text { apoptotic index is the mean number of apoptotic cells detected by active caspase } 3 \text { immuoreactivity per colonic } \\
\text { crypt in colon }\end{array}$} \\
\hline
\end{tabular}

a, b, c: different letters in the same line indicate statistically significant difference

$* * P<0.01, * * * P<0.001$

The number of PCNA positive cells per crypt column was decreased in the hormonetreated groups in comparison to group $\mathrm{C}(p<0.001)$. On the other hand, PCNA positive cell numbers in the groups $\mathrm{E}$ and $\mathrm{P}$ were lower than that of group $\mathrm{E}+\mathrm{P}$.

Similarly, PI in the hormone-treated groups was lower than that of group $\mathrm{C}(p<0.001)$. In addition, PI in group $\mathrm{P}$ was lower than that of the other hormone-treated groups (Plate VIII, Fig. 1).

AI was significantly decreased in group E. However, it was significantly increased in groups $\mathrm{P}$ and $\mathrm{E}+\mathrm{P}$, compared to group $\mathrm{C}$ (Fig. 2). 


\section{Discussion}

There are controversial results regarding the effects of oestrogen on the colon epithelium according to previous studies. Bullough et al. (1946) have reported an oestrogenstimulated mitosis in the colon crypt epithelium. On the other hand, Galand et al. (1967) reported that the duration of the DNA synthesis $(\mathrm{S})$ phase and, consequently, the cell cycle time became shortened in epithelial cells in four segments of intestine, following oestrogen administration to Ovx mice. In addition, Tutton and Barkla (1982) have suggested that ovariectomy reduced the mitotic rate in dimethylhydrazine-induced tumours of the rat colon and this effect was reversible by treatment of the Ovx animals with oestradiol benzoate but not with progesterone acetate. Similarly, a recent study based on Ovx mice (Cho et al. 2007) showed that the size and proliferation of proximal colon crypt epithelium were decreased due to the removal of hormonal effects; however, oestrogen replacement in Ovx mice reversed this effect, increasing colon crypt cell proliferation. On the contrary, Hoff and Chang (1979) have reported that ovariectomy was associated with colonic crypt hypoplasia and that treatment with oestradiol accentuated the hypoplasia. They have also reported inhibition of the DNA synthesis and indicated that it caused crypt hypoplasia in the colon of male mice (Hoff et al. 1981). In our study, we have demonstrated that both the crypt size and cell proliferation decreased in group E (Fig. 1), similarly as reported by Hoff and Chang (1979). Consistently, several studies have suggested that oestrogens exert a protective role against the development of colon cancer through indirect and direct effects on the colonic epithelium. Reasons for this protective effect include an oestrogeninduced decrease of both secondary bile acids and insulin-like growth factor I (IGF-I), a direct effect on the proliferation of colorectal epithelium, or a combination of these (Pasi and Robert 2000).

ERs have possible roles in the mechanism of these controversial effects. In a number of studies, both ER $\alpha$ and ER $\beta$ have been reported to express in the colon (CampbellThompson et al. 2001; Qiu et al. 2002; Xie et al. 2004; Cho et al. 2007). The two receptors function in opposite ways; ER $\beta$ activates apoptosis whereas ER $\alpha$ acts as a survival factor. Thus, oestrogen-induced apoptosis in colon cancer cell expressing ER $\beta$. On the other hand, it has been previously reported that ER $\beta$ is the predominant ER expressed in colonic tissues and frequently lost in colon tumours (CampbellThompson et al. 2001; Konstantinopoulos et al. 2003; Wada-Hiraike et al 2006). Although ER $\beta$ which induces apoptosis, acts as a dominant regulator of oestrogen signalling in healthy colonic tissue, in the present study we have determined that AI decreased in group E (Fig. 2) in parallel with previously mentioned decrease in proliferation $(p<0.001)$. Qui et al. (2002) have demonstrated that in CACO-2, LoVo and SW620 expressing both receptors, oestrogen have no effect on apoptosis. Consequently, it is possible that oestrogen can not induce apoptosis in healthy colon mucosa in which both receptors were detectable. It is well known that increased proliferation and decreased apoptosis are the main features of neoplasia. Thus, cell proliferation in healthy colon mucosa must be exactly balanced by cell loss in order to maintain homeostasis (Johnson et al. 1994). Also in this colon homeostasis, oestrogen signalling via $E R \alpha$ and ER $\beta$ plays an important role (Cho et al. 2007; Wada-Hiraike et al. 2006) and our findings are consistent with this view.

To our knowledge, the effects of progesterone treatment on cell population kinetics of the colon crypt in Ovx animals have not been reported yet. However, Cheng and Bjerkna (1988) demonstrated that colon crypt size decreased and the number of cells in $\mathrm{S}$ phase increased during proestrus and oestrus periods of the oestrus cycle, in which both progesterone and oestrus blood levels are high in mouse. Contrary to findings by Cheng and Bjerkna (1988), we determined that the crypt size slightly decreased in groups 
$\mathrm{P}$ and $\mathrm{E}+\mathrm{P}$, and it was not statistically significant. In addition, a significant decrease was determined in the number of proliferative cells, so as in the PI in those two groups, particularly in P group. Progesterone causes more decrease in PI than oestrogen. Besides, progesterone significantly increased the AI, contrary to that caused by oestrogen. Hence, it can be suggested that $\mathrm{P}$ has both anti-proliferative and apoptotic effects. On the other hand, considerably high AI in group E + P may suggest that the anti-apoptotic effect of oestrogen is depressed by progesterone. Although P receptors have been found in the colonic tissue, it is not certain whether the $\mathrm{P}$ has a direct action and/or indirect action on the colonic tissue.

Recently some epidemiological studies have suggested that combined oestrogen and progestogen hormone replacement therapy reduces the incidence of colorectal cancer in postmenopausal women (Rossouw et al. 2002; Nelson et al. 2002; Farquhar et al. 2005). Consequently, long term $E$ and $P$ treatment seem to have a protective effect against colorectal cancer. Hoff and Chang (1979) reported that although there is an increase in the number of proliferative cells, crypt size becomes smaller after ovariectomy. They concluded that the new steady-state status of the crypt in the Ovx animal had an intrinsic capacity to maintain proliferation and differentiation of epithelial cells despite the decreased crypt size depending on ovarian hormones.

Tutton and Barkla (1982) reported that ovariectomy did not make any difference in the crypt size and crypt cell proliferation. Cho et al. (2007) showed that the size and proliferation of proximal colon crypt epithelium was decreased due to the removal of hormonal effects. On the contrary, in our study the ovarian hormones administered to Ovx rats have decreased the proliferation of the colon crypt epithelium. Therefore, we can suggest that the effects of ovarian hormone removal caused an increase in cell proliferation in agreement with findings by Hoff and Chang (1979). Epithelial cell proliferation is also modulated by growth factors as well as hormones (Jones et al. 1999). Thus, growth factors may increase epithelial cell proliferation in the colon crypt when regulatory effects of hormones in colonic homeostasis are removed. It is interesting to observe the lowest crypt size in group $\mathrm{E}$ despite the anti-proliferative and apoptotic effects of $\mathrm{P}$ hormone. In our study, $17 \beta$-oestradiol and progesterone hormones were given for 15 days following ovariectomy. Thus, it can be suggested that $17 \beta$-oestradiol shows its effects very rapidly and progesterone needs longer time to be effective. Further studies need to be carried out based on the changes in the number of days and doses.

\section{Účinek ovariálních steroidů na proliferaci a apoptózu epiteliálních buněk kolonu potkanů}

Cílem této studie bylo zjistit vliv ovariálních steroidů na proliferaci a apoptózu epiteliálních buněk v kryptách kolonu. Studie byla provedena na dospělých kastrovaných (Ovxovariektomie) potkanech (Sprague Dawley). Ovx potkanům bylo injekčně podáváno po 15 dní 0,2 $\mathrm{ml}$ sezamového oleje (kontrolní skupina $\mathrm{C}$ ), nebo $17 \beta$-oestradiol $\left(10 \mu \mathrm{g} \cdot \mathrm{d}^{-1} ; \mathrm{E}\right)$, nebo progesteron $(2$ $\mathrm{mg} \cdot \mathrm{l}^{-1} ; \mathrm{P}$ ), neboE+P.Proliferativníaktivita vkolonu byla hodnocena s využitím PCNA(proliferating cell nuclear antigen) protilátek. Byl určen proliferační index (PI), tj. počet PCNA pozitivních buněk vydělených celkovým počtem buněk v kryptách kolonu, vynásobený stem. Proliferační index (PI) bylnižší u hormonálně ošetřených skupin, zvláštěu skupiny Pvesrovnání se skupinou C. Apoptotický index(AI), tj.průměrný početbuněk vapoptóze, byl stanoven mírouimunoreaktivity nakaspásu 3 v kryptách kolonu. Apoptotický index (AI) byl nejnižší v epitelu krypt kolonu skupiny E a v epitelu krypt kolonu skupin P a E+P byl vyšší než u skupiny E a C. Navíc velikost krypt kolonu (počet epiteliálních buněk vystýlajících 10 dobře orientovaných podélných řezu krypt) byl u skupiny E ve srovnání s ostatními skupinami významně nižší. Ve výsledku se ukázalo, že pokles AI u skupiny E byl vyrovnáván progesteronem a také pokles PI u skupiny byl potlačován estrogenem. 


\section{Acknowledgement}

This research was partially supported by the Scientific and Technological Research Council of Turkey.

\section{References}

BULLOUGH WS 1946: Mitotic activity in the adult female mouse, Mus musculus L. A study of its relation to the oestrous cycle in normal and abnormal conditions. Biol Sci 231: 453-516

CAMPBELL-THOMPSON M, LYNCH IJ, BHARDWAJ B 2001: Expression of estrogen receptor (ER) subtypes and ERbeta isoforms in colon cancer. Cancer Res 15: 632-640

CHENG H, BJERKNES M 1988: Variation of mouse intestinal epithelial whole population cell kinetics during the estrous cycle. Anat Rec 220: 397-400

CHLEBOWSKI RT, WACTAWSKI-WENDE J, RITENBAUGH C, HUBBELL FA, ASCENSAO J, RODABOUGH RJ, ROSENBERG CA, TAYLOR VM, HARRIS R, CHEN C, ADAMS-CAMPBELL LL, WHITE E 2004: Estrogen plus progestin and colorectal cancer in postmenopausal women. N Engl J Med 350: 991-1004

CHO NL, JAVID SH, CAROTHERS AM, REDSTON M, BERTAGNOLLI MM 2007: Estrogen receptors alpha and beta are inhibitory modifiers of Apc-dependent tumorigenesis in the proximal colon of Min/+ mice. Cancer Res 67: 2366-2372

DI DOMENICO M, CASTORIA G, BILANCIO A, MIGLIACCIO A, AURICCHIO F 1996: Oestradiol activation of human colon carcinoma-derived Caco-2 cell growth. Cancer Res 56: 4516-4521

FARQUHAR CM, MARJORIBANKS J, LETHABY A, LAMBERTS Q, SUCKLING JA 2005: Long term hormone therapy for perimenopausal and postmenopausal women. Cochrane Database Syst Rev 3: CD004143

GALAND P, RODESCH F, LEROY F, CHRETIEN J 1967: Altered duration of DNA synthesis and cell cycle in non target tissues of mice treated with oestrogen. Nature 216: 1211-1212

HISHIKAWA Y, DAMAVANDI E, IZUMI S, KOJI T 2003: Molecular histochemical analysis of estrogen receptor alpha and beta expressions in the mouse ovary: in situ hybridization and Southwestern histochemistry. Med Electron Microsc 36: 67-73

HOFF MB, CHANG WW 1979: The effect of estrogen on epithelial cell proliferation and differentiation in the crypts of the descending colon of the mouse: a radioautographic study. Am J Anat 155: 507-516

HOFF MB, CHANG WW, MAK KM 1981: Effect of estrogen on cell proliferation in colonic mucosa of the mouse. Virchows Arch B Cell Pathol Incl Mol Pathol 35: 263-273

JOHNSON LR, MC CORMACK SA 1994: Regulation of gastrointestinal mucosal growth. In: JOHNSON LR (Ed.): Physiology of the gastrointestinal tract. Raven Press, New York, pp. 611-641

JONES MK, TOMIKAWA M, MOHAJER B, TARNAWSKI AS 1999: Gastrointestinal mucosal regeneration: role of growth factors. Front Biosci 15: 303-309

KONSTANTINOPOULOS PA, KOMINEA A, VANDOROS G, SYKIOTIS GP, ANDRICOPOULOS P, VARAKIS I, SOTIROPOULOU-BONIKOU G, PAPAVASSILIOU AG 2003: Oestrogen receptor beta (ERbeta) is abundantly expressed in normal colonic mucosa, but declines in colon adenocarcinoma paralleling the tumour's dedifferentiation. Eur J Cancer 39: 1251-1258

MEGGOUH F, LOİNTIER P, PEZET D, SAEZ S 1991: Status of sex steroid hormone receptors in large bowel cancer. Cancer 67:1964-1970

NELSON HD, HUMPHREY LL, NYGREN P, TEUTSCH SM, ALLAN JD 2002: Postmenopausal hormone replacement therapy: scientific review. J Am Med Assoc 288: 872-881

QIU Y, WATERS CE, LEWIS AE, LANGMAN MJ, EGGO MC 2002: Oestrogen-induced apoptosis in colonocytes expressing oestrogen receptor beta. J Endocrinol 174: 369-377

PASI AJ, ROBERT JM 2000: Chemoprevention of colorectal cancer. N Engl J Med 342: 1960-1968

ROSSOUW JE, ANDERSON GL, PRENTICE RL, LACROIX AZ, KOOPERBERG C, STEFANICK ML, JACKSON RD, BERESFORD SA, HOWARD BV, JOHNSON KC, KOTCHEN JM, OCKENE J 2002: Risks and benefits of estrogen plus progestin in healthy postmenopausal women: principal results From the Women's Health Initiative randomized controlled trial. J Am Med Assoc 288: 321-333

SLATTERY ML, POTTER JD, CURTIN K, EDWARDS S, MAKN, ANDERSON K, SCHAFFER D, SAMOWITZ WS 2001: Estrogens reduce and withdrawal of estrogens increase risk of microsatellite instability-positive colon cancer. Cancer Res 61:126-130

SMIRNOFF P, LIEL Y, GNAINSKY J, SHANY S, SCHWARTZ B 1999: The protective effect of estrogen against chemically induced murine colon carcinogenesis is associated with decreased $\mathrm{CpG}$ island methylation and increased mRNA and protein expression of the colonic vitamin D receptor. Oncol Res 11:255-264

TUTTON PJ, BARKLA DH 1982: Differential effects of oestrogenic hormones on cell proliferation in the colonic crypt epithelium and in colonic carcinomata of rats. Anticancer Res 2: 199-201

TUTTON PJ, BARKLA DH 1988: Steroid hormones as regulators of the proliferative activity of normal and neoplastic intestinal epithelial cells (review). Anticancer Res 8: 451-456

XIE LQ, YU JP, LUO HS 2004: Expression of estrogen receptor beta in human colorectal cancer. World J Gastroenterol 10: 214-217

XU X, THOMAS ML 1994: Estrogen receptor-mediated direct stimulation of colon cancer cell growth in vitro. Mol Cell Endocrinol 105: 197-201 
WADA-HIRAIKE O, IMAMOV O, HIRAIKE H, HULTENBY K, SCHWEND T, OMOTO Y, WARNER M, GUSTAFSSON JA 2006: Role of estrogen receptor beta in colonic epithelium. Proc Natl Acad Sci USA 103: 2959-2964

WADA-HIRAIKE O, WARNER M, GUSTAFSSON JA 2006: New developments in oestrogen signalling in colonic epithelium. Biochem Soc Trans 34: 1114-1116

WINTER DC, TAYLOR C, C O'SULLIVAN G, HARVEY BJ 2000: Mitogenic effects of oestrogen mediated by a non-genomic receptor in human colon. Brit J Surg 87: 1684-1689 

Plate VIII

Altunbas K.: The Effect of ... pp. 605-612
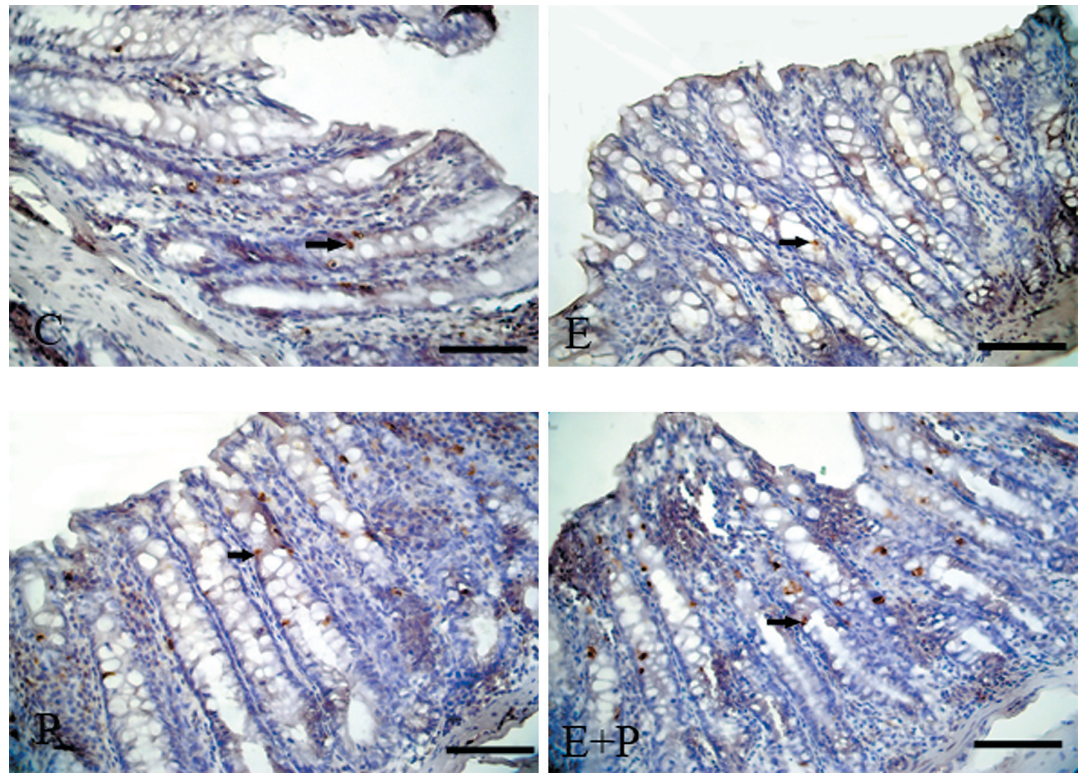

Fig. 1. Proliferating cell nuclear antigen (PCNA) positive cells in rat colon crypt epithelium. C: Control; E: Oestrogen; P: Progesterone; E+P: Estrogen+Progesterone

Arrow - PCNA localization in colon crypt epithelium. Bar - $100 \mu \mathrm{m}$.

Other details see legend to Table 1.
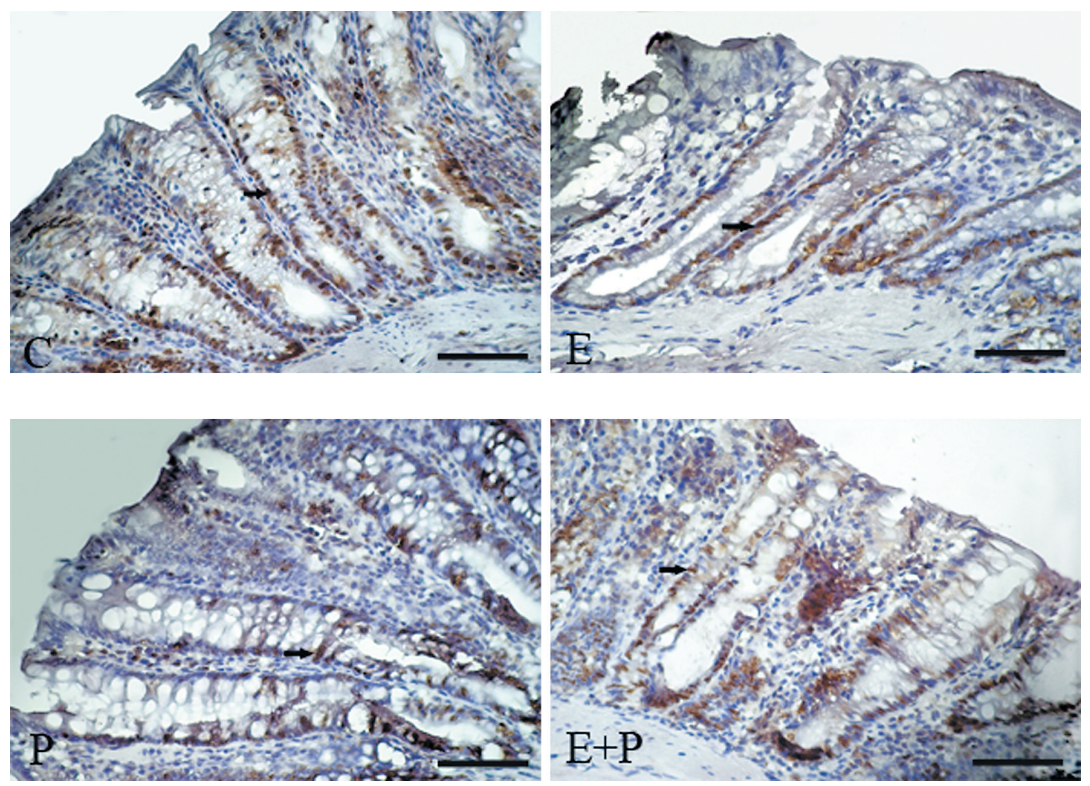

Fig. 2. Apoptosis in rat colon crypt epithelium. C: Control; E: Oestrogen; P: Progesterone; E+P: Estrogen+Progesterone

Arrow - active caspase 3 localization in colon crypt epithelium. Bar $100 \mu \mathrm{m}$.

Other details see legend to Table 1. 
